\title{
NUTRITIONAL STRATEGIES TO IMPROVE NITROGEN USE EFFICIENCY BY GRAZING DAIRY COWS
}

\author{
Juan Pablo Keim ${ }^{1 *}$, and René Anrique ${ }^{1}$
}

Grazing dairy cows are characterized by converting a low proportion of dietary $\mathrm{N}$ into milk $\mathrm{N}$. This low $\mathrm{N}$ use efficiency (NUE) is mainly due to an excessive supply of crude protein $(\mathrm{CP})$ of pasture with regard to animal requirements. Excess $\mathrm{N}$ in the diet has negative effects for the animal; it alters the organoleptic characteristics of milk and pollutes the environment through $\mathrm{N}$ excretions. The aim of this review was to analyze the available information on nutritional strategies to improve NUE by grazing dairy cows, such as diluting the dietary $\mathrm{N}$ through supplementation, synchronizing ruminal carbohydrate (CHO), and $\mathrm{N}$ fermentation rates, and using pastures with a high water soluble carbohydrates (WSC) content. There is a beneficial effect of carbohydrate supplementation on NUE, with an increase in milk yield (MY) of $0.83 \pm 0.34 \mathrm{~kg}^{\mathrm{milk} \mathrm{kg}}{ }^{-1}$ supplement and a reduction of ammonia $\mathrm{N}\left(\mathrm{NH}_{3}-\mathrm{N}\right)$ in the rumen. A better synchrony between $\mathrm{CHO}$ and rumen $\mathrm{N}$ does not improve MY and NUE. However, a positive effect on NUE was identified as a result of increasing the WSC/CP ratio. The use of cultivars with high WSC content increases the dry matter intake (DMI), MY, and milk N production, with no consistent effect on NUE.

Key words: Concentrate supplementation, ruminal synchrony, high sugar ryegrass, crude protein, milk production.

$\mathrm{O}$ ne of the objectives of animal nutrition is to provide the amount of nutrients that the animal needs to achieve a certain level of production. Any deficiency will translate into a lower production, while an excessive nutrient supply involves losses that will increase production costs and can also affect the animal and the environment (Hristov and Jouany, 2005; Pacheco et al., 2008).

Grazing systems, compared to confinement systems which provide a balanced ration, reach lower levels of production and nutritional efficiency. An example of this situation is the low conversion of dietary $\mathrm{N}$ into milk $\mathrm{N}$, ranging between 13 and $31 \%$ in grazing systems and 40 to $45 \%$ under confinement systems with balanced rations (Delagarde et al., 1997; Verité and Delaby, 2000). A low N use efficiency (NUE) is basically due to the incapacity of animals to build significant amounts of protein reserves, being necessary to adjust protein supply according to protein requirements (Hoekstra et al., 2007). Energy is the main limiting nutrient for productivity under grazing conditions, while amino acids supply usually exceeds animal requirements (Kolver et al., 1998).

Dietary $\mathrm{N}$ which is not converted into milk $\mathrm{N}$ has negative effects on the animal, reducing energy availability

${ }^{1}$ Universidad Austral de Chile, Facultad de Ciencias Agrarias, Independencia 641, Valdivia, Chile

"Corresponding author (juan.keim@uach.cl).

Received: 16 February 2011.

Accepted: 10 August 2011. due to the energy spent in the conversion of ammonia $\left(\mathrm{NH}_{3}\right)$ into urea (Pacheco et al., 2008); besides excess dietary $\mathrm{N}$ it is associated with reproductive problems (Butler, 1998), lower dry matter intake (DMI; Cosgrove et al., 1999), risk of intoxication due to excess nitrates (Bolan and Kemp, 2003), undesirable odors or flavors in milk (Bendall, 2001) and environmental pollution, mainly through excretion of urinary N (UN; Pacheco et al., 2008). Due to the negative effects related to low NUE, it is necessary and challenging to develop strategies that allow increasing NUE in dairy systems. Under confinement conditions there are several approaches to optimize the proportion of dietary $\mathrm{N}$ converted into milk $\mathrm{N}$ (Verité and Delaby, 2000; Castillo et al., 2001; Hristov and Jouany, 2005; Flachowsky and Lebzien, 2006; Hoekstra et al., 2007), unfortunately there is still uncertainty about the pathways that may improve NUE under grazing dairy systems.

This review is focused on analyzing factors that explain the low NUE of grazing systems in temperate regions, and the nutritional strategies that have been evaluated to improve the conversion of dietary $\mathrm{N}$ into milk $\mathrm{N}$, such as reducing $\mathrm{N}$ content of pastures, lowering $\mathrm{N}$ content of the diet through supplementation, improving ruminal synchrony between energy and protein, and the use of Lolium perenne L. cultivars with a high sugar content.

\section{Nitrogen metabolism}

Nitrogen utilization in ruminants occurs through a series of processes that take place in the rumen and 
the animal. While rumen bacteria can metabolize a variety of $\mathrm{N}$ sources, animals need amino acids for their metabolism (Pacheco and Waghorn, 2008). Therefore, the requirements of both microorganisms and host must be taken into consideration when formulating diets.

In ruminants, $\mathrm{N}$ arrives to the small intestine as microbial protein, ruminal undegraded protein (RUP) and as endogenous protein, and collectively contribute to metabolizable protein (MP; Schwab et al., 2005). Microbial protein is highly digestible and is characterized by a balanced amino acid profile, while in RUP the amino acid composition resembles that of the precursor feed (NRC, 2001). Total digestible protein in the small intestine corresponds to MP composed by amino acids and peptides that are absorbed and made available for animal metabolism (Lapierre et al., 2005), while excess MP is deaminated by the liver and excreted as urea through the urine (Bohnert et al., 2002). Therefore, as $\mathrm{N}$ intake increases urinary $\mathrm{N}$ increases considerably with no effect on fecal $\mathrm{N}$, being urinary $\mathrm{N}$ the main determinant of the negative relationship between $\mathrm{N}$ intake and NUE (Figure 1).

Microbial protein is the result of microbial metabolism and in most cases represents the main source of the amino acids absorbed by the intestine (70 to $100 \%$ ) of the host animal (Schwab et al., 2005). Microbial protein is synthesized mainly from $\mathrm{NH}_{3}$ (38 to $80 \%$ ) generated from protein degradation (Pacheco and Waghorn, 2008) and peptides, when protein is rapidly degraded in the rumen (Hristov and Jouany, 2005; Nolan and Dobos, 2005).

The amount of microbial protein synthesized depends on the nutritional quality of the feed, intake level and retention time of solids and liquids in the rumen (NRC, 2001; Hristov and Jouany, 2005; Nolan and Dobos, 2005) and may potentially reach $50 \mathrm{~g}$ per $100 \mathrm{~g} \mathrm{CP}$ ingested (Pacheco et al., 2008). In terms of nutritional factors influencing microbial protein synthesis it is important to consider the nature of energy and $\mathrm{N}$ sources, among them; microbial growth and the efficiency of $\mathrm{NH}_{3}$ utilization are highly determined by the availability of carbohydrates (CHO) in the rumen (Newbold and Rust, 1992; Heldt et al., 1999). Therefore, the control of factors associated to $\mathrm{CHO}$ availability in the rumen, such as the

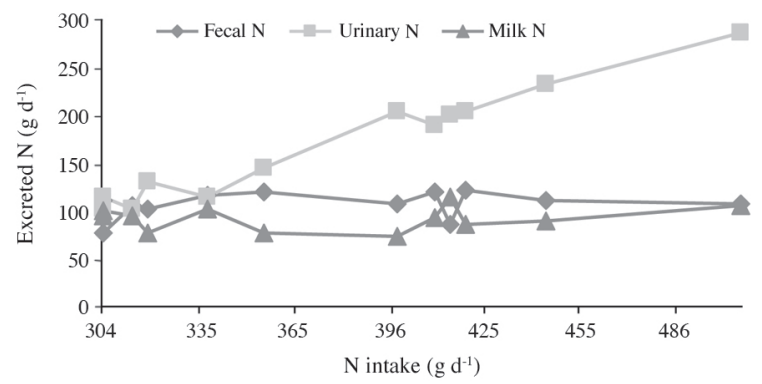

Figure 1. Relationship between $\mathrm{N}$ intake and $\mathrm{N}$ excreted in milk, feces and urine (adapted from Steinshamn et al., 2006). amount supplemented, its source and degradability, and the synchronization between the rate of release of energy and $\mathrm{N}$ in the rumen could help improving the efficiency of ruminal $\mathrm{NH}_{3}$ and dietary $\mathrm{N}$ utilization (Hristov and Jouany, 2005).

The concentration of ruminal $\mathrm{NH}_{3}$ increases when intake of rumen degradable protein (RDP) is high compared to fermentable energy, favoring $\mathrm{NH}_{3}$ absorption and transport to the liver for urea synthesis (Castillo et al., 2001; Kulling et al., 2001). Urea is released into the blood stream and excreted through the urine, normally allowing toxic effects associated to excessive ammonia to be avoided (Lapierre et al., 2005). The detoxification process has an energy cost of 4 moles of ATP per mol of urea synthesized (McBride and Kelly, 1990), which is equivalent to $7.17 \mathrm{kcal} \mathrm{ME} \mathrm{g}^{-1} \mathrm{~N}$ as urea (Tyrell, 1970; cited by Pacheco and Waghorn, 2008) or to $3.3 \mathrm{kcal} \mathrm{ME}$ $\mathrm{g}^{-1}$ urea.

In lactating dairy cows, between a 60 and $90 \%$ of ingested $\mathrm{N}$ is eliminated through feces and urine depending on $\mathrm{N}$ intake and production level (Flachowsky and Lebzien, 2006). Urinary $\mathrm{N}$ excretions up to $500 \mathrm{~g} \mathrm{~d}^{-1}$ have been measured with high $\mathrm{N}$ intake (Steinshamn et al., 2006; Pacheco and Waghorn, 2008).

\section{Pasture as a source of nitrogen}

In dairy systems based on high quality pastures (2.75-2.9 Mcal ME kg-1 DM), energy supply is regarded as the main limiting factor for milk production, allowing to sustain production levels of up to $27 \mathrm{~L} \mathrm{cow}^{-1} \mathrm{~d}^{-1}$, while protein is not limiting with production levels up to $35 \mathrm{~L} \mathrm{cow}^{-1} \mathrm{~d}^{-1}$ (Kolver et al., 1998).

The $\mathrm{N}$ contained in forages is found as proteins, peptides, free amino acids, nucleic acids, nitrates, and secondary metabolites (Goswami and Willcox, 1969). True protein (TP) normally ranges between 70 and $90 \%$ of total CP (Tamminga, 1986) and RDP (Pacheco and Waghorn, 2008). The RUP content in fresh pasture is generally low and with values ranging between $11.7,8$ and $3 \% \mathrm{CP}$ for a permanent pasture with $27 \% \mathrm{CP}$, adjusted for rumen passage rate of 8,5 and $2 \% \mathrm{~h}^{-1}$, respectively (Anrique et al., 2008). Also RUP increases slightly with longer grazing intervals (Hoekstra et al., 2007).

$\mathrm{CP}$ content and $\mathrm{N}$ fractions of pastures are variable and influenced by factors such as botanical composition and season of the year (Fulkerson et al., 1998; Aufrere et al., 2003), also by physiological stage and agronomical managements (Peyraud and Astigarraga, 1998). Increasing $\mathrm{N}$ fertilization tends to increase $\mathrm{CP}$ and non protein $\mathrm{N}$ (NPN) content in the plant, and also degradability of $\mathrm{N}$ fractions in rumen, therefore decreasing the contribution of RUP (Nolan and Dobos, 2005). Pastures undergoing intensive $\mathrm{N}$ fertilization have reached $\mathrm{CP}$ levels higher than $300 \mathrm{~g} \mathrm{~kg}^{-1} \mathrm{DM}$ (Pacheco et al., 2008) with NPN concentrations from 240 to $420 \mathrm{~g} \mathrm{~kg}^{-1}$ total $\mathrm{N}$ (Goswami and Willcox, 1969), thus increasing the risk of negative 
effects on the animal and the environment and achieving a low NUE (Cosgrove et al., 1999; Bendall, 2001; Bolan and Kemp, 2003; Pacheco et al., 2008). The low NUE obtained under grazing conditions is basically due to the high dietary $\mathrm{N}$ intake, coupled with a high concentration of soluble protein and an imbalance and asynchrony between protein and energy supplies to the rumen (Nolan and Dobos, 2005; Hoekstra et al., 2007; Pacheco and Waghorn, 2008), and represents a loss of $\mathrm{N}$ and energy potentially available for productive purposes (Pacheco et al., 2008).

NUE of grazing dairy cows ranges between 13 and $31 \%$ (Verité and Delaby, 2000), with higher efficiency being observed with low $\mathrm{CP}$ content in the ration and high milk productions (Bach et al., 2000; Pacheco et al., 2008). As it has been possible to store in the milk up to $45 \%$ of the ingested $\mathrm{N}$ under experimental conditions (Delagarde et al., 1997), we believe that it may be possible to increase NUE in grazing dairy systems by developing nutritional strategies to reduce $\mathrm{N}$ intake and optimize microbial protein synthesis.

\section{Strategies to improve $\mathrm{N}$ use efficiency in grazing systems}

Several authors have suggested strategies to improve NUE (Verité and Delaby, 2000; Castillo et al., 2001; Hristov and Jouany, 2005; Flachowsky and Lebzien, 2006; Hoekstra et al., 2007; Pacheco et al., 2008; Pacheco and Waghorn, 2008), that under grazing conditions are restricted to the following: i) reducing $\mathrm{N}$ intake from the pasture, ii) synchronizing $\mathrm{CHO}$ and $\mathrm{N}$ supply in the rumen through supplements, iii) by using forage species with high WSC and of lower CP contents.

Reducing $\mathbf{N}$ intake from pasture based diets. A reduction of $\mathrm{N}$ content in pastures may be achieved through agronomic management such as selecting forage species with lower $\mathrm{N}$ content, which is a long term process, or by reducing the amount of $\mathrm{N}$ supplied as fertilizer or by increasing grazing intervals (Peyraud and Astigarraga, 1998). However, reducing $\mathrm{N}$ fertilization can decrease forage yield and longer grazing intervals should reduce the nutritional quality of the pasture. On the other hand, providing supplements with a low $\mathrm{CP}$ content is an alternative that allows diluting dietary $\mathrm{N}$ concentration (Pacheco et al., 2008), may not affect milk production and may increase stocking rate on the farm.

The purpose of supplementation to improve NUE should be focused on decreasing dietary CP content, avoiding an excess of $\mathrm{CP}$ available in the rumen, and increasing the energy supply to help converting dietary $\mathrm{N}$ into microbial protein (Hristov and Jouany, 2005; Pacheco et al., 2008).

A higher synthesis of microbial protein would reduce $\mathrm{N}$ excretions only if there is enough energy to allow the differential of absorbed amino acids to be retained in milk
(Flachowsky and Lebzien, 2006; Pacheco et al., 2008) and if the animal has the genetic potential to produce a higher amount of milk protein (Chagunda et al., 2009).

The use of concentrates with low CP and high NSC contents has improved NUE (Keady et al., 1998), while using protein supplements increased considerably the $\mathrm{N}$ excretion through the urine and reduced NUE (Mulligan et al., 2004). Reducing CP content in the diet from 180 to $160 \mathrm{~g} \mathrm{~kg}^{-1}$, through ration formulation, made possible to maintain milk production, reduce $\mathrm{N}$ intake by 10 to 15 percentage units and $\mathrm{N}$ excretion by 13 to 20 percentage units (Satter et al., 2002), indicating the possibility to increase NUE by the reduction of CP in the diet without affecting milk production.

Table 1 summarizes the results from studies that analyzed the effect of using different $\mathrm{CHO}$ sources on productive and metabolic responses of grazing dairy cows. Pasture was the main component of the diet except for treatments in which the cows received up to $10 \mathrm{~kg}$ of concentrates. The CP content of the supplements ranged between 121 and $260 \mathrm{~g} \mathrm{~kg}^{-1}$, and an average NUE of 24 $\pm 4.8 \%$ (minimum 15.4 and maximum $32.9 \%: \mathrm{n}=52$ ) was observed. Based on 91 diets evaluated in different countries, Castillo et al. (2000) observed an average NUE of $28 \%$.

Cows consuming only pasture had a NUE of $21.0 \pm$ $6.1 \%$ while supplemented grazing cows improved their NUE, storing in the milk $24.6 \pm 3.8 \%$ of the ingested $\mathrm{N}$, showing a positive effect of $\mathrm{CHO}$ supplementation on NUE (Van Vuuren et al., 1993; Berzaghi et al., 1996; Carruthers and Neil, 1997; Robaina et al., 1998; Reis and Combs, 2000; Walker et al., 2001; Bargo et al., 2002; Steinshamn et al., 2006). This improvement may be due to a decrease in CP content of the diet and to an increase of microbial protein synthesis. However, it is important to highlight that the improvement of $\mathrm{NUE}$ as a response to $\mathrm{CHO}$ supplementation occurs mainly when the pasture has a $\mathrm{CP}$ content higher than $200 \mathrm{~g} \mathrm{~kg}^{-1}$ (Van Vuuren et al., 1993; Berzaghi et al., 1996; Reis and Combs, 2000; Bargo et al., 2002); whereas with a lower CP content the effects are less important (Carruthers and Neil, 1997; O'Mara et al., 1997; Robaina et al., 1998; Walker et al., 2001; Steinshamn et al., 2006). Nevertheless, the highest reported values of NUE under grazing conditions are still lower than the ones obtained with cows fed total mixed rations (TMR), indicating that despite $\mathrm{CHO}$ supplementation there is still the possibility to develop other strategies that could improve NUE even more under grazing conditions.

The results summarized in Table 1 also show that the ruminal $\mathrm{NH}_{3}-\mathrm{N}$ decreases with energy supplementation (Van Vuuren et al., 1993; Berzaghi et al., 1996; Carruthers and Neil, 1997; O'Mara et al., 1997; Jones-Endsley et al., 1997; Reis and Combs, 2000; Bargo et al., 2002), which suggests a higher $\mathrm{NH}_{3}-\mathrm{N}$ utilization for microbial protein synthesis (Berzaghi et al., 1996; Carruthers and Neil, 1997; O’Mara, 1997). 
Table 1. Effects of reducing the CP content of the diet by carbohydrate supplementation on NUE and milk production in grazing dairy cows.

\begin{tabular}{|c|c|c|c|c|c|c|c|c|}
\hline PI & SI & $\mathrm{CP}$ & $\mathrm{NH}_{3}-\mathrm{N}$ & $\mathrm{MN}$ & $\mathrm{EN}$ & MY & NUE & Authors \\
\hline \multicolumn{2}{|c|}{$-\mathrm{kg} \mathrm{d}^{-1}-$} & \multirow{2}{*}{$\begin{array}{l}\mathrm{g} \mathrm{kg}^{-1} \\
201\end{array}$} & $\mathrm{mg} \mathrm{dL}^{-1}$ & \multicolumn{2}{|c|}{$-\mathrm{g} \mathrm{d}^{-1}-$} & \multirow{2}{*}{$\begin{array}{l}\mathrm{kg} \mathrm{d}^{-1} \\
\mathrm{NA}\end{array}$} & \multirow{2}{*}{$\%$} & \multirow{14}{*}{$\begin{array}{l}\text { Van Vuuren et al., } \\
1993\end{array}$} \\
\hline 13.0 & 0.0 & & 22.0 & $\mathrm{NA}$ & NA & & & \\
\hline 8.3 & 5.0 & 185 & 16.0 & NA & NA & NA & 29.0 & \\
\hline 8.3 & 4.9 & 182 & 14.5 & NA & NA & NA & 29.0 & \\
\hline 10.5 & 6.6 & 201 & 20.3 & NA & NA & NA & 26.0 & \\
\hline 9.1 & 6.7 & 198 & 20.1 & NA & NA & NA & 27.0 & \\
\hline 9.5 & 7.1 & 196 & 13.5 & NA & NA & NA & 28.0 & \\
\hline 10.2 & 7.3 & 204 & 16.7 & NA & NA & NA & 27.0 & \\
\hline 11.4 & 0.0 & 260 & 32.5 & NA & NA & NA & 16.0 & \\
\hline 9.3 & 4.5 & 215 & 21.3 & NA & NA & NA & 22.0 & \\
\hline 9.5 & 3.8 & 222 & 21.6 & NA & NA & NA & 20.0 & \\
\hline 11.6 & 0.0 & 260 & 33.4 & NA & NA & NA & 16.0 & \\
\hline 9.3 & 4.0 & 218 & 28.3 & NA & NA & NA & 21.0 & \\
\hline 9.9 & 4.3 & 214 & 27.1 & NA & NA & NA & 21.0 & \\
\hline 13.0 & 0.0 & 251 & 22.4 & 88 & 434 & 19.5 & 16.9 & \multirow{2}{*}{$\begin{array}{c}\text { Berzaghi et al., } \\
1996\end{array}$} \\
\hline 9.8 & 5.4 & 194 & 17.1 & 109 & 362 & 23.7 & 23.1 & \\
\hline 14.5 & 0.0 & 176 & 17.6 & 100 & 301 & 19.9 & 24.9 & \multirow{4}{*}{$\begin{array}{l}\text { Carruthers and Neil } \\
1997\end{array}$} \\
\hline 14.3 & 1.3 & 161 & 13.2 & 106 & 286 & 20.3 & 27.0 & \\
\hline 14.3 & 0.0 & 132 & 7.5 & 96 & 215 & 18.7 & 30.8 & \\
\hline 14.0 & 1.3 & 121 & 5.4 & 98 & 210 & 18.8 & 31.8 & \\
\hline 13.6 & 0.0 & 152 & 7.2 & 109 & 221 & 21.4 & 32.9 & \multirow{2}{*}{$\begin{array}{c}\text { O’Mara et al., } \\
1997\end{array}$} \\
\hline 11.5 & 2.7 & 143 & 5.6 & 103 & 223 & 19.8 & 31.6 & \\
\hline 11.7 & 6.4 & 214 & 19.1 & 110 & 510 & 24.8 & 17.8 & \multirow{2}{*}{$\begin{array}{c}\text { Jones-Endsley et al. } \\
1997\end{array}$} \\
\hline 10.5 & 9.6 & 204 & 17.6 & 113 & 543 & 25.4 & 17.2 & \\
\hline 14.9 & 0.0 & 179 & NA & 68 & 359 & 14.0 & 16.0 & \multirow{4}{*}{$\begin{array}{c}\text { Robaina et al., } \\
1998\end{array}$} \\
\hline 12.3 & 4.4 & 170 & NA & 85 & 369 & 16.4 & 18.7 & \\
\hline 12.1 & 0.0 & 179 & NA & 53 & 293 & 10.6 & 15.4 & \\
\hline 10.7 & 4.3 & 170 & NA & 74 & 334 & 14.8 & 18.2 & \\
\hline 13.9 & 0.0 & 195 & 22.5 & 99 & 334 & 21.8 & 22.9 & \multirow{3}{*}{$\begin{array}{l}\text { Reis and Combs, } \\
2000\end{array}$} \\
\hline 12.7 & 5.0 & 172 & 17.7 & 127 & 361 & 26.8 & 26.0 & \\
\hline 9.7 & 10.0 & 155 & 13.8 & 148 & 343 & 30.4 & 30.2 & \\
\hline 12.1 & 0.0 & 153 & NA & 63 & 234 & 12.4 & 21.2 & \multirow{14}{*}{$\begin{array}{l}\text { Walker et al., } \\
\qquad 2001\end{array}$} \\
\hline 12.0 & 3.0 & 152 & NA & 83 & 282 & 15.6 & 22.8 & \\
\hline 11.2 & 5.0 & 143 & NA & 98 & 273 & 18.3 & 26.3 & \\
\hline 10.6 & 7.0 & 145 & NA & 105 & 303 & 19.9 & 25.7 & \\
\hline 10.4 & 9.0 & 145 & NA & 111 & 339 & 20.7 & 24.7 & \\
\hline 9.2 & 10.4 & 140 & NA & 119 & 320 & 21.9 & 27.2 & \\
\hline 9.9 & 0.0 & 121 & NA & 49 & 143 & 10.0 & 25.4 & \\
\hline 9.8 & 3.0 & 124 & NA & 60 & 194 & 11.8 & 23.5 & \\
\hline 9.8 & 5.0 & 125 & NA & 74 & 222 & 14.8 & 24.9 & \\
\hline 9.8 & 7.0 & 126 & NA & 83 & 256 & 16.9 & 24.4 & \\
\hline 15.0 & 0.0 & 135 & NA & 78 & 246 & 15.5 & 24.2 & \\
\hline 14.3 & 3.0 & 131 & NA & 94 & 269 & 18.4 & 25.8 & \\
\hline 13.1 & 4.9 & 131 & NA & 96 & 281 & 18.3 & 25.4 & \\
\hline 12.2 & 5.9 & 132 & NA & 98 & 285 & 18.2 & 25.5 & \\
\hline 17.5 & 0.8 & 202 & 15.2 & 91 & 500 & 19.1 & 15.4 & \multirow{4}{*}{$\begin{array}{l}\text { Bargo et al., } \\
\quad 2002\end{array}$} \\
\hline 15.2 & 8.6 & 172 & 9.1 & 146 & 508 & 29.7 & 22.4 & \\
\hline 20.5 & 0.7 & 194 & 15.3 & 104 & 554 & 22.2 & 15.8 & \\
\hline 16.1 & 8.7 & 169 & 8.7 & 149 & 522 & 29.9 & 22.2 & \\
\hline 13.4 & 5.0 & 164 & NA & 141 & 341 & 29.6 & 29.3 & \multirow{3}{*}{$\begin{array}{l}\text { Mulligan et al., } \\
2004\end{array}$} \\
\hline 15.4 & 0.8 & 193 & NA & 144 & 355 & 27.6 & 28.4 & \\
\hline 13.9 & 5.0 & 203 & NA & 152 & 467 & 32.3 & 24.6 & \\
\hline 15.9 & 0.0 & 157 & NA & 114 & 286 & 24.9 & 28.5 & \multirow{2}{*}{$\begin{array}{l}\text { Steinshamn et al., } \\
2006\end{array}$} \\
\hline 14.7 & 1.8 & 156 & NA & 126 & 285 & 26.9 & 30.6 & \\
\hline
\end{tabular}

PI: pasture intake; SI: supplement intake; $\mathrm{CP}$ : dietary crude protein content; $\mathrm{NH}_{3}-\mathrm{N}$ : ruminal ammonia N; MN: milk N; EN: N excreted through urine and feces; MY: milk yield; NUE: $N$ use efficiency; NA: not available.

Since animals do not have the ability to store the excess of ingested N (Hoekstra et al., 2007), as N intake increases, milk and fecal $\mathrm{N}$ concentrations remain relatively constant, while the amount of urinary $\mathrm{N}$ excreted increases proportionally (Steinshamn et al., 2006) reaching levels closer to $50 \%$ of total ingested $\mathrm{N}$ (Hristov and Jouany, 2005). In the reviewed studies, the amounts of urinary and fecal $\mathrm{N}$ vary with $\mathrm{CHO}$ supplementation, with positive (Jones-Endsley et al., 1997; Robaina et al.,
1998; Reis and Combs, 2000; Walker et al., 2001), neutral (O'Mara, 1997; Bargo et al., 2002) or negative responses (Berzaghi et al., 1996; Bargo et al., 2002). This may be caused by a number of factors determining the $\mathrm{N}$ losses, such as the CP concentration of the supplement and the ration, a possible increase of the total DMI caused by the supplementation, an increase of the amount of available energy for microbial protein synthesis, and a possible decrease of DM digestibility as a consequence of a lower ruminal $\mathrm{pH}$. If concentrate supplementation does not dilute $\mathrm{CP}$ concentration of the diet, it may not decrease the urinary $\mathrm{N}$ excretions, because the surplus of ingested $\mathrm{N}$ regarding $\mathrm{N}$ requirements would not be reduced. Furthermore, if DMI increases and CP concentration of the diet remains constant, higher amounts of daily urinary $\mathrm{N}$ excretions may be expected.

It has been observed that in supplemented dairy cows there was an increase of the proportion of fecal $\mathrm{N}$ compared to urinary N (Van Vuuren et al., 1993; Carruthers and Neil, 1997; Bargo et al., 2002; Mulligan et al., 2004; Steinshamn et al., 2006). As mentioned above, fecal N should remain relatively constant, but could increase due to a higher DMI and a lower $\mathrm{N}$ digestibility. When the MP meets animal requirements, increasing microbial protein synthesis or RUP supply may have no effect on NUE, but may produce an increase in the proportion of fecal $\mathrm{N}$ in relation to urinary $\mathrm{N}$ (Flachowsky and Lebzien, 2006; Pacheco et al., 2008), which corresponds to the indigestible fraction of MP and RUP at intestinal level. When higher amounts of circulating $\mathrm{N}$ are converted into fecal microbial $\mathrm{N}$, via fermentation in the posterior digestive tract, a transference of potential urinary $\mathrm{N}$ to fecal $\mathrm{N}$, an environmentally less labile source of $\mathrm{N}$, could be achieved (Gressley and Armentano, 2007) and therefore the potential impact on the environment may be reduced.

The effect of $\mathrm{CHO}$ supplementation on pasture diets has been also analyzed using continuous culture fermenters, evaluating ruminal digestion and $\mathrm{N}$ metabolism (Bach $e t$ al., 1999; Bargo et al., 2003; Wales et al., 2009). Ruminal $\mathrm{NH}_{3}-\mathrm{N}$ decreased as a consequence of supplementation. The amount of microbial $\mathrm{N}$ produced $\left(\mathrm{g} \mathrm{d}^{-1}\right)$ kept constant, however, with low and medium substitution rates $(\mathrm{kg}$ pasture $\mathrm{kg}^{-1}$ concentrate) there was an increase in the proportion of microbial $\mathrm{N}$ in relation to total $\mathrm{N}$ flow (Bargo et al., 2003). In other CHO supplementation experiments, it has been found a significant increase in bacterial $\mathrm{N}$ synthesis (Bach et al., 1999), or no response (Wales et al., 2009) compared with a pasture only diet. In order to avoid a negative effect on the OM digestibility and efficiency of microbial protein synthesis ( $\mathrm{g} \mathrm{N} \mathrm{kg}^{-1}$ digested $\left.\mathrm{OM}\right)$, it has been suggested that grain inclusion should not exceed $24 \%$ of total diet (Wales et al., 2009). At higher levels the efficiency of microbial $\mathrm{N}$ synthesis tends to decrease with supplementation (Bach et al., 1999; Bargo et al., 2003).

From a productive point of view, concentrate 
supplementation of grazing dairy cows causes an increase in milk production (Berzaghi et al., 1996; Carruthers and Neil, 1997; Robaina et al., 1998; Ries and Combs, 2000; Walker et al., 2001; Bargo et al., 2002; Mulligan et al., 2004; Steinshamn et al., 2006), however, the response observed has been variable with a media of $0.83 \pm 0.34(\mathrm{n}=23) \mathrm{kg}$ milk kg-1 supplement and lower than in confinement, limiting the use of this alternative to the relationship between price paid per liter of milk, the cost per kilogram of supplement and the animal response. The highest milk production in supplemented grazing dairy cows usually occurs due to an increase in total DMI and digestibility of the diet. However, there are several factors affecting the milk response (MR) like herbage allowance, amount and type of supplement, and production level and stage of lactation of the cow. Higher herbage allowances are related to higher substitution rates (SR; SR = (pasture DMI in unsupplemented treatment - pasture DMI in supplemented treatment)/supplement DMI), a small increase in total DMI and therefore a lower MR to concentrate supplementation. The milk response per kilogram of concentrate decreases as the amount of concentrate increases, being lower above $3-4 \mathrm{~kg}$ concentrate $\mathrm{d}^{-1}$ when pasture quality and quantity are not limiting. Finally, cows in early lactation have a higher MR than cows in late lactation.

In summary, supplementation with energy sources and low protein content increases NUE in grazing dairy cows, due to a decrease in the CP content of the diet and a possible higher microbial protein synthesis. Another beneficial effect is that it decreases the proportion of urinary $\mathrm{N}$ in relation to fecal $\mathrm{N}$, since the last one has a lower impact on the environment. Supplementation decreases pasture intake per cow, allowing increasing the stocking rate, and a higher milk yield per cow. So it would allow producing more milk protein per surface unit with lower losses to the environment (Verité and Delaby, 2000). However, the milk response to supplementation, the price paid per liter of milk and the cost per kilogram of supplement must be considered to avoid a negative effect on the profitability of the dairy farm.

Improving ruminal synchrony between $\mathrm{CHO}$ and $\mathrm{N}$. The concept of ruminal synchrony proposed by Johnson (1976) establishes that ruminal $\mathrm{NH}_{3}$ utilization and microbial protein synthesis would be maximized if there is a synchrony between the availability of energy and $\mathrm{N}$ in the rumen (balanced amounts at the same time). This could be achieved by changing the $\mathrm{CHO}$ or $\mathrm{N}$ sources, changing the feeding patterns (time of supplementation regarding grazing) or the feeding frequency (Cabrita et al., 2006). A better ruminal synchrony could be achieved under grazing systems, when the $\mathrm{CHO}$ sources have a degradation rate of 13 to $14 \% \mathrm{~h}^{-1}$, because this is similar to the RDP degradation rate of the pasture (Van Vuuren et al., 1990), although degradation rate of the pasture will vary with different circumstances (Aufrere et al., 2003).

Table 2 shows the results obtained in experiments aiming at improving ruminal synchrony between $\mathrm{CHO}$ and $\mathrm{N}$, either by changing the fermentation rates of $\mathrm{CHO}$ and $\mathrm{N}$ through modification of the diet ingredients (Shabi et al., 1998; Casper et al., 1999; Gehman et al., 2006) or changing the feeding patterns (Kolver et al., 1998; Trevaskys et al., 2004; Lund et al., 2008).

Casper et al. (1999) evaluated the supplementation with corn (Zea mays L.) or barley (Hordeum vulgare L.) plus soybean (Glycine max Merr.) meal or extruded soybean meal to improve ruminal synchrony between CHO and N, while Gehman et al. (2006) determined the effect of supplementing grazing cows with corn, barley or citrus pulp. None of these studies could determine any clear effects on NUE when modifying the degradation rate of $\mathrm{CHO}$ and $\mathrm{CP}$, however, Casper et al. (1999) observed a tendency towards a higher NUE when supplementing with barley and soybean meal (synchrony due to the fast degradation of $\mathrm{CHO}$ and $\mathrm{CP}$ ) and corn with extruded soybean meal (synchrony due to the lower degradation rate of $\mathrm{CHO}$ and $\mathrm{CP}$ ), and determined lower amounts of ruminal $\mathrm{NH}_{3}-\mathrm{N}$ (barley plus soybean meal), which indicates a better utilization of $\mathrm{N}$ for the synthesis of microbial protein. Meanwhile, milk production was higher in diets supplemented with corn as a consequence of a higher DMI. Total intake can decrease when supplementing with large amounts of rapidly degradable $\mathrm{CHO}$ sources, due to a decrease of OM digestibility and a lower ruminal passage rate (Chamberlain and Wilkinson, 1996). Gehman et al. (2006) determined a higher NUE when supplementing with corn (C) or barley (B) rather than when using citrus pulp (CIP), even though considering the synchrony the supplementation with $\mathrm{B}$ or CIP should increase NUE, since their degradation rate (13 a $14 \% \mathrm{~h}^{-1}$ ) would be expected to allow an optimum ruminal $\mathrm{NH}_{3}$ utilization by grazing dairy cows. Experimentally, a disadvantage of modifying the ingredients of the diet is that there are effects that could be attributed to ruminal synchrony, when they would actually be a consequence of factors linked to the supplemented ingredient (Hristov and Jouany, 2005). In order to identify effects that are a consequence of better ruminal synchronization, it is recommended to change the feeding patterns (Newbold and Rust, 1992), specifically, the moment when the supplement is offered to the animals in relation to the grazing event.

From the studies of Kolver et al. (1998), Trevaskys et al. (2004), and Lund et al. (2008) we define a synchronized diet as the one where the highest proportion of rapidly degradable $\mathrm{CHO}$ was supplemented before grazing to match the energy supply (from the degradation of the $\mathrm{CHO}$ in the supplement) and $\mathrm{NH}_{3}$ content at the rumen (from the degradation of $\mathrm{CP}$ of the pasture). In the three studies there was a decrease in $\mathrm{N}$ intake for diets with a better synchrony, but only Trevaskys et al. (2004) found 
Table 2. Effects of applying supplementation strategies, to optimize carbohydrate and nitrogen synchronization, on NUE and milk production of grazing dairy cows.

\begin{tabular}{|c|c|c|c|c|c|c|c|c|}
\hline Supplementation criteria & DMI & $\mathrm{NI}$ & MY & $\mathrm{NH}_{3}-\mathrm{N}$ & UN & $\mathrm{MN}$ & NUE & Authors \\
\hline & $\mathrm{kg} \mathrm{d}^{-1}$ & $\mathrm{~g} \mathrm{~d}^{-1}$ & $\mathrm{~kg} \mathrm{~d}^{-1}$ & \multicolumn{2}{|c|}{$\mathrm{mg} \mathrm{dL}^{-1}$} & $\mathrm{~g} \mathrm{~d}^{-1}$ & $\%$ & \multirow{3}{*}{ Kolver et al., 1998} \\
\hline BG & 18.8 & 491.3 & 29.1 & 16.3 & $21.8^{*}$ & 121.3 & 24.7 & \\
\hline $\mathrm{AG}$ & 19.3 & 510.0 & 29.9 & 18.4 & $22.3^{*}$ & 125.0 & 24.5 & \\
\hline $75 \% \mathrm{BG}, 25 \% \mathrm{PM}$ & 14.7 & 791.0 & 25.1 & NA & NA* & 124.4 & 16.0 & \multirow{2}{*}{ Trevaskys et al., 2004} \\
\hline $25 \% \mathrm{BG}, 75 \% \mathrm{PM}$ & 14.7 & 836.0 & 24.3 & NA & NA* & 126.8 & 14.9 & \\
\hline SMAM, BPM P1 & 19.2 & 555.2 & 31.1 & NA & $7.4^{* *}$ & 157.1 & 28.3 & \multirow{4}{*}{ Lund et al., 2008} \\
\hline BAM, SMPM P1 & 18.5 & 524.8 & 30.6 & NA & $6.6^{* *}$ & 154.1 & 29.4 & \\
\hline SMAM, BPM P2 & 18.6 & 520.0 & 25.8 & NA & $7.7 * *$ & 144.0 & 27.7 & \\
\hline BAM, SMPM P2 & 18.0 & 497.6 & 25.1 & NA & $7.2 * *$ & 140.0 & 28.1 & \\
\hline ROM/RCP & 16.7 & 432.0 & 18.5 & 16.6 & $17.6^{* *}$ & 101.5 & 23.5 & \multirow{4}{*}{ Shabi et al., 1998} \\
\hline $\mathrm{ROM} / \mathrm{SCP}$ & 16.4 & 432.0 & 18.2 & 14.4 & $17.0 * *$ & 99.8 & 23.1 & \\
\hline $\mathrm{SOM} / \mathrm{RCP}$ & 15.5 & 400.0 & 17.5 & 18.2 & $19.9 * *$ & 93.3 & 23.3 & \\
\hline SOM/SCP & 16.1 & 416.0 & 18.2 & 15.3 & $19.8 * *$ & 97.0 & 23.3 & \\
\hline $\mathrm{C}$ & 25.0 & 592.0 & 30.6 & NA & $10.1 *$ & 134.8 & 22.8 & \multirow{3}{*}{ Gehman et al., 2006} \\
\hline $\mathrm{B}+\mathrm{M}$ & 22.8 & 560.0 & 29.9 & NA & $11.4^{*}$ & 129.8 & 23.2 & \\
\hline $\mathrm{CP}+\mathrm{M}$ & 25.2 & 592.0 & 30.0 & NA & $9.9 *$ & 127.0 & 21.4 & \\
\hline $\mathrm{C}+\mathrm{S}$ & 20.7 & 549.8 & 25.1 & 15.0 & $19.1 * *$ & 127.5 & 23.2 & \multirow{4}{*}{ Casper et al., 1999} \\
\hline $\mathrm{C}+\mathrm{ES}$ & 21.8 & 593.0 & 27.5 & 10.4 & $18.4^{* *}$ & 143.1 & 24.1 & \\
\hline$B+S$ & 19.9 & 509.4 & 23.8 & 9.0 & $18.1 * *$ & 123.8 & 24.3 & \\
\hline $\mathrm{B}+\mathrm{ES}$ & 20.0 & 537.6 & 23.5 & 11.3 & $20.0 * *$ & 119.3 & 22.2 & \\
\hline
\end{tabular}

DMI: dry matter intake; NI: nitrogen intake; MY: milk yield; $\mathrm{NH}_{3}-\mathrm{N}$ : ruminal ammonia N; UN: urea N; MN: milk N; NUE: N use efficiency; NA: not available; *: milk urea N; **: plasma urea N; BG: supplementation at beginning of grazing; AG: supplementation $4 \mathrm{~h}$ after grazing: $75 \% \mathrm{BG}, 25 \% \mathrm{PM}$ : $75 \%$ of the supplement before grazing, $25 \%$ during afternoon milking; 25\%BG, $75 \%$ PM: $25 \%$ of the supplement before grazing, $75 \%$ during afternoon milking; SMAM, BPM: soybean meal supplied in the morning and barley in the afternoon; BAM, SMPM: barley supplied in the morning and soybean meal in the afternoon; ROM/RCP: rapidly degradable organic matter, rapidly degradable crude protein; HOM/SCP: rapidly degradable organic matter, slowly degradable crude protein; SOM/RCP: slowly degradable organic matter, rapidly degradable crude protein; SOM/SCP: slowly degradable organic matter, slowly degradable crude protein; C: corn; B + M: barley plus molasses; CP + M: citric pulp plus molasses; C + S: corn plus soybean; C + ES: corn plus extruded soybean; B + S: barley plus soybean; B + ES: barley plus extruded soybean.

a slight increase of NUE $(+1.1 \%)$, as a consequence of a lower CP content in the pasture of the treatment with better synchrony ( $308 \mathrm{vs} .328 \mathrm{~g} \mathrm{~kg}^{-1}$ ). There were no differences in MY and urea $\mathrm{N}$ levels. The effects of synchrony in MY and N excretion are not clear (Newbold and Rust, 1992; Hristov and Jouany, 2005) and less important than expected (Cabrita et al., 2006). A proof of this is that Kaswari et al. (2007) did not obtain significant differences between isoenergetic and isoproteic diets with different synchrony indexes for ruminal $\mathrm{N}-\mathrm{NH}_{3}$ content, microbial protein synthesis, and metabolizable energy flow. Factors explaining the lack of response with synchronizing degradation of $\mathrm{CHO}$ and $\mathrm{N}$, may be that ruminants have the capacity to recycle the excess $\mathrm{N}$ into urea and supply it to the rumen during periods of deficit, remaining available for microbial protein synthesis when slowly degradable $\mathrm{CHO}$ are fermented and release energy (Marini et al., 2004; Lapierre et al., 2005), also ruminal bacteria can recover rapidly from $\mathrm{N}$ shortages (Newbold and Rust, 1992), so that their metabolic functions are not affected.

The lack of response to a higher synchrony in cows fed pastures with high CP content (more than $200 \mathrm{~g} \mathrm{~kg}^{-1}$ on DM basis) would be caused by an excess of MP in relation to the requirements of dairy cows (for a milk production of around $30 \mathrm{~L} \mathrm{~d}^{-1}$ ), therefore the animal would not be able to convert the higher MP supply, generated by a better synchrony, into milk N (Trevaskys et al., 2004). Cows with a higher genetic merit for protein synthesis could store a higher amount of consumed $\mathrm{N}$ in milk (Chagunda et al., 2009). Therefore selecting cows with higher milk protein production would allow depositing the excess of $\mathrm{MP}$ at the intestinal level into milk $\mathrm{N}$.

\section{Increase of water soluble carbohydrate concentration of the pasture}

Effect of agronomic management. A higher WSC content in the forage allows to decrease $\mathrm{N}$ intake and urinary $\mathrm{N}$, because there is an inverse relationship between sugar content and CP of the forages (Tas et al., 2006b). Therefore, the beneficial effects of forages with a high WSC content should be a consequence of a higher energy supply at the rumen and a lower $\mathrm{N}$ intake (Taweel, 2006).

It is possible to improve the $\mathrm{WSC} / \mathrm{CP}$ ratio by reducing $\mathrm{N}$ fertilization (Taweel, 2006), increasing grazing intervals (Peyraud and Astigarraga, 1998), using selected cultivars with high sugar content (Miller et al., 2001), or adjusting the pasture intake according to the daily patterns of WSC and CP contents of the plant (Trevaskys et al., 2004). WSC concentration in grasses is higher at sunset than during the morning (Rutter et al., 2004; Hristov and Jouany, 2005) as a consequence of sugar accumulation (especially sucrose) due to photosynthesis, finding higher levels at the moment when photosynthesis and respiration rates are equal. Meanwhile CP content is higher during the morning than at sunset, because there is a negative relationship between WSC and CP content (Cosgrove et al., 2007).

In theory, maximizing animal DMI at sunset would allow to improve NUE. Forage samples that were collected at sunset have a wider $\mathrm{WSC} / \mathrm{CP}$ ratio than those collected at the morning (Trevaskys et al., 2004). Trevaskys et al. (2004) determined the effect of offering a daily strip of pasture to dairy cows in the morning or the afternoon, observing an increase in DMI, MY, milk $\mathrm{N}$ content and NUE when the cattle entered the pasture in the afternoon (Table 3). Nevertheless, due to 
the high CP content of the pasture (328 and $268 \mathrm{~g} \mathrm{~kg}^{-1}$ $\mathrm{DM}$, in the morning and afternoon, respectively), NUE remained within low standards (13.9 and $16.3 \%$ for cows entering the field in the morning and afternoon, respectively).

Use of high sugar varieties. Miller et al. (2001) evaluated milk production in late lactating dairy cows fed a perennial ryegrass pasture, selected for a high WSC content (HS), or a standard cultivar. They observed a higher digestible DMI $\left(+1.5 \mathrm{~kg} \mathrm{~d}^{-1}\right)$, greater MY $\left(+2.7 \mathrm{~kg} \mathrm{~d}^{-1}\right)$ and NUE $(+7 \%)$, and a lower proportion of urinary $\mathrm{N}(10 \%)$ in cows fed the HS cultivar. Two years later in a similar study with early lactation cows, Moorby et al. (2006) determined a higher WSC content (243 vs. $161 \mathrm{~g} \mathrm{~kg}^{-1} \mathrm{DM}$ ), higher digestibility and a lower NDF content for the HS cultivar as compared to the control, resulting in a higher pasture (15.3 vs. $13.1 \mathrm{~kg}$ $\left.\mathrm{DM} \mathrm{d}^{-1}\right)$ and total DMI (18.8 vs. 16.6) and a non significant tendency to a higher milk yield $\left(+2.3 \mathrm{~kg} \mathrm{~d}^{-1}\right)$. However there were no differences in NUE, but values (average of 36.7\%) are very high for grazing cows, which was attributed to the low CP content of the pasture (average $101.5 \mathrm{~g} \mathrm{~kg}^{-1} \mathrm{DM}$ ). In this experiment urinary $\mathrm{N}$ decreased $7 \%$ and fecal $\mathrm{N}$ increased $14 \%$ for cows fed HS, which would lessen the environmental impact associated to $\mathrm{N}$ excretions for cows fed HS cultivars.
Taweel et al. (2005) evaluated an HS perennial ryegrass with lactating dairy cows $(126 \pm 21 \mathrm{DIM})$. The HS cultivars had $20 \%$ more WSC than standard cultivars and, as a different from Miller et al. (2001) and Moorby et al. (2006) findings, their NDF and CP contents were similar, so the observed responses could be attributed to the increase in WSC content. There were no significant differences for pasture DMI, total DMI, digestible DMI, $\mathrm{MY}$, and NUE, while MUN and ruminal $\mathrm{NH}_{3}-\mathrm{N}$ tended to be lower in cows fed the HS cultivar. In a subsequent study Taweel et al. (2006) did not observe differences in DMI, MY, and NUE in early lactation cows $(75 \pm 7 \mathrm{~d})$ fed with HS and standard cultivars. The reason behind the lack of response with feeding HS cultivars, observed in these two studies, could be that an increase in WSC content of around $20 \%$ would not be enough to increase palatability and forage digestibility (Taweel et al., 2005; 2006). Although there was a difference in WSC content between HS and standard cultivars, the energy and CP content were similar, so the only difference between HS and standard cultivars was the ruminal $\mathrm{CHO}$ rate of degradation. As discussed above, the effects off modifying $\mathrm{CHO}$ and $\mathrm{N}$ degradation i.e. ruminal synchrony does not increase milk yield neither NUE. Even though MUN was lower for HS varieties, indicating a possible higher microbial protein synthesis, the CP levels of the diets

Table 3. Effect of water soluble carbohydrate content in the pasture on NUE and milk production of grazing dairy cows.

\begin{tabular}{|c|c|c|c|c|c|c|c|c|c|}
\hline & WSP & $\mathrm{CP}$ & DMI & MY & MUN & EN & MN & NUE & Authors \\
\hline & \multicolumn{2}{|c|}{$\mathrm{g} \mathrm{kg}^{-1}$} & \multicolumn{2}{|c|}{$\mathrm{kg} \mathrm{d}^{-1}$} & $\mathrm{mg} \mathrm{dL}^{-1}$ & \multicolumn{2}{|c|}{$\mathrm{g} \mathrm{d}^{-1}$} & $\%$ & \multirow{3}{*}{ Trevaskys et al., 2004} \\
\hline PAM & 74 & 328 & 14.7 & 24.3 & NA & 720 & 116 & 13.9 & \\
\hline P PM & 124 & 268 & 16.4 & 26.8 & NA & 699 & 136 & 16.3 & \\
\hline HS & 165 & 92 & 15.1 & 15.3 & NA & 197 & 83 & 29.8 & \multirow[t]{2}{*}{ Miller et al., 2001} \\
\hline Control & 126 & 106 & 14.2 & 12.6 & NA & 223 & 68 & 23.3 & \\
\hline HS & 243 & 104 & 18.8 & 32.7 & NA & 240 & 136 & 36.2 & \multirow[t]{2}{*}{ Moorby et al., 2006} \\
\hline Control & 161 & 99 & 16.6 & 30.4 & NA & 201 & 119 & 37.2 & \\
\hline HS & 181 & 159 & 20.2 & 23.8 & 18.3 & 361 & 129 & 26.1 & \multirow{4}{*}{ Taweel et al., 2005} \\
\hline Control & 157 & 162 & 20.6 & 24.7 & 20.5 & 377 & 131 & 25.6 & \\
\hline HS & 180 & 151 & 20.3 & 25.1 & 16.7 & 340 & 132 & 27.8 & \\
\hline Control & 149 & 157 & 21.1 & 26.6 & 19.9 & 367 & 141 & 27.5 & \\
\hline HS & 129 & 184 & 18.4 & 27.5 & NA & 404 & 135 & 24.9 & \multirow[t]{2}{*}{ Taweel et al., 2006} \\
\hline Control & 105 & 186 & 17.6 & 26.9 & NA & 389 & 131 & 25.0 & \\
\hline HS Y 1 & 149 & 183 & 17.5 & 28.1 & 14.0 & 433 & 137 & 24.1 & \multirow{8}{*}{ Tas et al., 2006a } \\
\hline LS Y 1 & 132 & 175 & 17.5 & 27.0 & 14.5 & 411 & 128 & 23.8 & \\
\hline LS Y 1 & 110 & 182 & 15.6 & 26.0 & 15.6 & 382 & 124 & 24.4 & \\
\hline HS Y 1 & 144 & 179 & 18.0 & 28.8 & 14.4 & 435 & 139 & 24.2 & \\
\hline HS Y 2 & 114 & 210 & 17.0 & 25.8 & 16.0 & 499 & 124 & 19.9 & \\
\hline LS Y 2 & 107 & 195 & 17.3 & 25.8 & 15.0 & 482 & 123 & 20.3 & \\
\hline LS Y 2 & 87 & 207 & 17.4 & 25.2 & 16.5 & 515 & 117 & 18.5 & \\
\hline HS Y 2 & 131 & 194 & 18.4 & 25.7 & 14.9 & 499 & 124 & 19.9 & \\
\hline c1 Y1 & 192 & 160 & 20.2 & 26.9 & 8.8 & 373 & 144 & 27.8 & \multirow{12}{*}{ Tas et al., 2006b } \\
\hline $\mathrm{c} 2 \mathrm{Y} 1$ & 170 & 157 & 21.5 & 28.1 & 9.4 & 393 & 147 & 27.3 & \\
\hline c3 Y1 & 158 & 166 & 21.4 & 26.3 & 9.6 & 420 & 141 & 25.1 & \\
\hline c4 Y1 & 195 & 150 & 20.1 & 26.8 & 7.3 & 348 & 139 & 28.5 & \\
\hline c5 Y1 & 172 & 156 & 20.9 & 27.9 & 8.8 & 376 & 146 & 28.0 & \\
\hline c6 Y1 & 152 & 159 & 20.7 & 28.3 & 8.7 & 378 & 146 & 27.8 & \\
\hline $\mathrm{c} 1 \mathrm{Y} 2$ & 131 & 204 & 17.1 & 24.6 & 17.4 & 412 & 122 & 22.9 & \\
\hline c2 Y2 & 110 & 198 & 17.3 & 24.7 & 17.4 & 403 & 120 & 22.9 & \\
\hline c3 Y2 & 93 & 194 & 16.8 & 23.8 & 16.4 & 385 & 116 & 23.1 & \\
\hline $\mathrm{c} 4 \mathrm{Y} 2$ & 113 & 190 & 16.1 & 22.5 & 16.3 & 361 & 107 & 22.9 & \\
\hline c5 Y2 & 100 & 193 & 16.5 & 23.3 & 16.7 & 376 & 113 & 23.1 & \\
\hline c6 Y2 & 98 & 203 & 17.1 & 23.9 & 17.2 & 415 & 117 & 22.0 & \\
\hline
\end{tabular}

WSC: water soluble carbohydrates; CP: crude protein; DMI: dry matter intake; MY: milk yield; MUN: milk urea N; EN: excreted N; MN: milk N; NUE: N use efficiency; NA: not available; P AM: grazing started in the morning; P PM: grazing started in the afternoon; HS: cultivar with high WSC content; LS: standard cultivar. 
were sufficient to satisfy animal requirements, so that the difference of microbial protein would not be used for productive purposes.

Tas et al. (2006a) determined a higher WSC content for HS cultivars (210 to $260 \mathrm{~g} \mathrm{~kg}^{-1}$ for the first and second season of evaluation, respectively). WSC content decreased and the $\mathrm{CP}$ concentration increased during the second season, attributed to a higher $\mathrm{N}$ fertilization of the pasture. During 2002, DM and N intake, milk and protein production in early lactation cows was higher for HS cultivars, however, during 2003 there were no differences between HS and standard cultivars. MUN content was lower for the HS treatment during the two seasons. The increase in WSC content at the expense of the CP and NDF concentrations did not show the expected differences between cultivars for NUE during the two seasons (24.1 and $24.6 \%$ during 2002; 19 and $20.9 \%$ in 2003). Tas et al. (2006b) evaluated the productive response in early lactation dairy cows fed with six cultivars of perennial ryegrass that had different WSC content. The cultivars with higher WSC content showed a lower CP and NDF content, however, there were no differences in DMI and MY. There were no significant differences in NUE between cultivars.

The information in Table 3 allowed us to determine a high correlation $\left(\mathrm{r}^{2}=0.75\right)$ between the WSC/CP ratio and NUE (Figure 2), which tends to increase linearly (NUE = 9.329* $\mathrm{WSC} / \mathrm{CP}+16.57)$ as the $\mathrm{WSC} / \mathrm{CP}$ ratio increases, in other words, to improve NUE, it would be necessary to increase the WSC concentration and, simultaneously, decrease the CP content.

In summary, the use of HS cultivars increases DM intake (Miller et al., 2001; Moorby et al., 2006; Taweel et al., 2006), milk production (Miller et al., 2001; Moorby et al., 2006; Tas et al., 2006a; Taweel et al., 2006) and milk $\mathrm{N}\left(\mathrm{g} \mathrm{d}^{-1}\right)$. However, NUE improved consistently only in one study (Miller et al., 2001), while MUN decreased only in one experiment (Taweel et al., 2005). A higher milk production was observed when cows were fed with HS pasture, this was associated with a higher DMI but not to a better nutrient utilization (Miller et al., 2001; Trevaskys et al., 2004; Moorby et al., 2006; Tas et al., 2006a; Taweel et al., 2006). A higher, but not significant, NUE average was observed when cows consumed HS cultivars, when comparing with values obtained with cows fed conventional cultivars $(24.7 \pm 4.8 \%$ vs. 20.9 $\pm 5.9 \%$ ), however, this happened mainly because of the low CP content of the pastures evaluated, without an important effect of the increase in WSC content of the plant. Therefore, it would be expected that with permanent pastures such as those present in Southern Chile, characterized by a high CP content during autumn and spring (Anrique et al., 2008), NUE might be lower to those values described, despite the use of HS cultivars and close to those observed by Trevaskys et al. (2004).

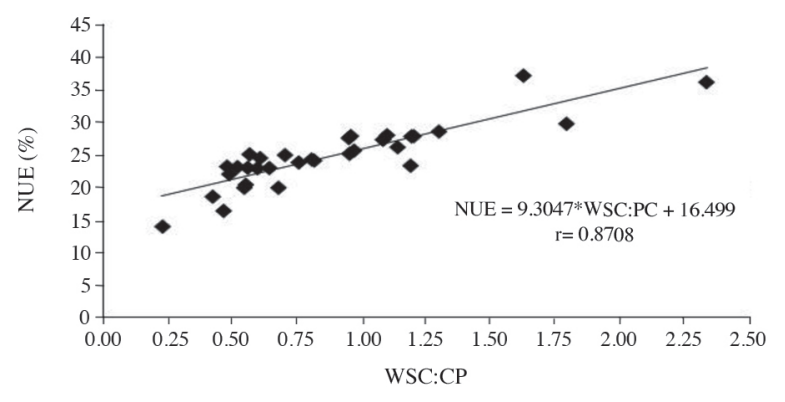

Figure 2. NUE as affected by the WSC:CP ratio of the pasture (data taken from Miller et al., 2001; Trevaskis et al., 2004; Taweel et al., 2005; 2006; Moorby et al., 2006; Tas et al., 2006a; 2006b).

\section{CONCLUSIONS}

A low NUE is observed in grazing dairy cows, which is attributed to the high CP content of most pastures in temperate areas during autumn and spring. The most efficient strategy to improve NUE and reduce urinary $\mathrm{N}$ under these conditions seems to be to reduce dietary $\mathrm{CP}$ content through supplementation with low-protein concentrate feeds. The supplementation allows increasing animal stocking rate and milk protein production per surface unit and decreases the loss per product unit. A better ruminal synchrony has not meant a higher NUE under grazing conditions, while the use of HS cultivars shows inconsistent results.

In order to improve NUE it is necessary to increase the $\mathrm{WSC} / \mathrm{CP}$ ratio of the pasture plants. Therefore, a viable alternative would be to combine practices such as carbohydrate supplementation and to offer pasture during the afternoon. Additionally, genetic selection of dairy cows, orientated towards a higher concentration of milk protein, is important for cows to increase milk $\mathrm{N}$ retention.

\section{ACKNOWLEDGEMENTS}

To Dr. Luis Latrille for the valuable comments. Financial assistance provided by Dirección de Investigación y Desarrollo (DID)/Universidad Austral de Chile is gratefully acknowledged.

Estrategias nutricionales para mejorar la eficiencia de uso del nitrógeno en vacas lecheras en pastoreo. Las vacas lecheras en pastoreo se caracterizan por convertir una baja cantidad del $\mathrm{N}$ dietario en $\mathrm{N}$ lácteo. Esta baja eficiencia en el uso del N (NUE) se debe principalmente al excesivo suministro de proteína cruda $(\mathrm{CP})$ de la pradera en relación a los requerimientos del animal. El exceso de $\mathrm{N}$ en la dieta tiene efectos negativos para el animal, altera las características organolépticas de la leche y contamina el medio ambiente a través de las excreciones de N. El objetivo de este trabajo fue analizar la información disponible sobre estrategias nutricionales para mejorar 
EUN en vacas lecheras a pastoreo, tales como diluir la concentración de $\mathrm{N}$ dietario a través de la suplementación, sincronizar la tasa de fermentación de carbohidratos (CHO) y $\mathrm{N}$ en el rumen, y utilizar praderas con alto contenido de carbohidratos solubles (WSC). Se observa una relación beneficiosa entre la suplementación con CHO y la NUE, con un aumento en producción de leche (MY) de $0.83 \pm 0.34 \mathrm{~kg}$ leche $\mathrm{kg}^{-1}$ suplemento y menor cantidad de $\mathrm{N}$ amoniacal $\left(\mathrm{N}-\mathrm{NH}_{3}\right)$ en el rumen. La mejora en la sincronía entre $\mathrm{CHO}$ y $\mathrm{N}$ a nivel ruminal, no genera los efectos esperados en PL y EUN. Se observó un efecto positivo sobre la NUE al mejorar la relación WSC/CP. La utilización de cultivares con un mayor contenido de WSC incrementa el consumo de MS, MY y la cantidad de $\mathrm{N}$ lácteo, mientras que la NUE no mejora consistentemente.

Palabras clave: Suplementación con concentrados, sincronía ruminal, ballicas altas en azúcar, proteína cruda, producción de leche.

\section{LITERATURE CITED}

Anrique, R., R. Fuchslocher, S. Iraira, and R. Saldaña. 2008. Composición de alimentos para el ganado bovino. $3^{\mathrm{a}}$ ed. Imprenta América, Valdivia, Chile.

Aufrere, J., D. Graviou, and C. Demarquilly. 2003. Ruminal degradation of protein of cocksfoot and perennial ryegrass as affected by various stages of growth and conservation methods. Animal Research 52:245-261.

Bach, A., G.B. Huntington, S. Calsamiglia, and M.D. Stern. 2000. Nitrogen metabolism of early lactation cows fed diets with two different levels of protein and different amino acid profiles. Journal of Dairy Science 83:2585-2595.

Bach, A., I.K. Yoon, M.D. Stern, H.G. Jung, and H. Chester-Jones. 1999. Effects of type of carbohydrate supplementation to lush pasture on microbial fermentation in continuous culture. Journal of Dairy Science 82:153-160.

Bargo, F., L.D. Muller, J. Delahoy, and T.W. Cassidy. 2002. Milk response to concentrate supplementation of high producing dairy cows grazing at two pasture allowances. Journal of Dairy Science 85:1777-1792.

Bargo, F., G.A. Varga, L.D. Muller, and E.S. Kolver. 2003. Pasture intake and substitution rate effects on nutrient digestion and nitrogen metabolism during continuous culture fermentation. Journal of Dairy Science 86:1330-1340.

Bendall, J.G. 2001. Aroma compounds of fresh milk from New Zealand cows fed different diets. Journal of Agricultural and Food Chemistry 49:4825-4832.

Berzaghi, P., J.H. Herbein, and C.E. Polan. 1996. Intake, site, and extent of nutrient digestion of lactating cows grazing pasture. Journal of Dairy Science 79:1581-1589.

Bohnert, D.W., C.S. Schauer, and T. Delcurto. 2002. Influence of rumen protein degradability and supplementation frequency on performance and nitrogen use in ruminants consuming lowquality forage: cow performance and efficiency of nitrogen use in wethers. Journal of Animal Science 80:1629-1637.

Bolan, N.S., and P.D. Kemp. 2003. A review of factors affecting and prevention of pasture-induced nitrate toxicity in grazing animals. Proceedings of the New Zealand Grassland Association 65:171178.

Butler, W.R. 1998. Review: Effect of protein nutrition on ovarian and uterine physiology in dairy cattle. Journal of Dairy Science 81:2533-2539.
Cabrita, A.R., R.J. Dewhurst, J.M. Abreu, and A.J. Fonseca. 2006. Evaluation of the effects of synchronizing the availability of $\mathrm{N}$ and energy on rumen function and production responses of dairy cows - a review. Animal Research 55:1-24.

Carruthers, V.R., and P.G. Neil. 1997. Milk production and ruminal metabolites from cows offered two pasture diets supplemented with non-structural carbohydrate. New Zealand Journal of Agricultural Research 40:513-521.

Casper, D., H. Maiga, M. Brouk, and D. Schingoethe. 1999. Synchronization of carbohydrate and protein sources on fermentation and passage rates in dairy cows. Journal of Dairy Science 82:1779-1790.

Castillo, A.R., E. Kebreab, D.E. Beever, J.H. Barbi, J.D. Sutton, H.C. Kirby, and J. France. 2001. The effect of protein supplementation on nitrogen utilization in lactating dairy cows fed grass silage diets. Journal of Animal Science 79:247-253.

Castillo, A.R., E. Kebreab, D.E. Beever, and J. France. 2000. A review of efficiency of nitrogen utilization in lactating dairy cows in relationship with environmental pollution. Journal of Animal Feed Sciences 9:1-32.

Chagunda, M.G.G., D.A.M. Römer, and D.J. Roberts. 2009. Effect of genotype and feeding regime on enteric methane, non-milk nitrogen and performance of dairy cows during the winter feeding period. Livestock Science 122:323-332.

Chamberlain, A.T., and J.M. Wilkinson. 1996. Feeding the dairy cow. 241 p. Ed. Chalcombe Publications, Painshall, Welton, Lincoln, UK.

Cosgrove, G.P., J.L. Burke, A.F. Death, M.J. Hickey, D. Pacheco, and G.A. Lane. 2007. Ryegrasses with increased soluble carbohydrates: evaluating the potential for dairy grazing dairy cows in New Zealand. Proceedings of the New Zealand Grassland Association 69:179-185.

Cosgrove, G.P., G.C. Waghorn, and A.J. Parsons. 1999. Exploring the nutritional basis of preference and diet selection by sheep. Proceedings of the New Zealand Grassland Association 61:175180.

Delagarde, R., J.L. Peyraud, and L. Delaby. 1997. The effect of nitrogen fertilisation level and protein supplementation on herbage intake, feeding behaviour and digestion in grazing dairy cows. Animal Feed Science and Technology 66:165-180.

Flachowsky, G., and P. Lebzien. 2006. Possibilities for reduction of nitrogen $(\mathrm{N})$ excretion from ruminants and the need for further research - a review. Landbauforschung Volkenrode 56:19-30.

Fulkerson, W. J., K. Slack, D. W. Hennessy, and G. M. Hough. 1998. Nutrients in ryegrass "Lolium spp.", white clover "Trifolium repens" and kikuyu "Pennisetum clandestinum" pastures in relation to season and stage of regrowth in a subtropical environment. Australian Journal of Experimental Agriculture 38:227-240.

Gehman, A.M., J.A. Bertrand, T.C. Jenkins, and B.W. Pinkerton. 2006. The effect of carbohydrate source on nitrogen capture in dairy cows on pasture. Journal of Dairy Science 89:2659-2667.

Goswami, A.K., and J.S. Willcox. 1969. Effect of applying increasing levels of nitrogen to ryegrass. I. Composition of various nitrogenous fractions and free amino acids. Journal of the Science of Food and Agriculture 20:592-599.

Gressley, T.F., and L.E. Armentano. 2007. Effects of low rumendegradable protein or abomasal fructan infusion on diet digestibility and urinary nitrogen excretion in lactating dairy cows. Journal of Dairy Science 90:1340-1353.

Heldt, J.S., R.C. Cochran, C.P. Mathis, B.C. Woods, K.C. Olson, E.C. Titgemeyer, et al. 1999. Effects of level and source of carbohydrate and level of degradable intake protein on intake and digestion of low-quality tallgrass-prairie hay by beef steers. Journal of Animal Science 77:2846-2854.

Hoekstra, N.J., R.P.O. Schulte, P.C. Struik, and E.A Lantinga. 2007. Pathways to improving the $\mathrm{N}$ efficiency of grazing bovines. European Journal of Agronomy 26:363-374. 
Hristov, A.N., and J.P. Jouany. 2005. Factors affecting the efficiency of nitrogen utilization in the rumen. p. 117-166. In Pfeffer, E., and A.N. Hristov (eds.) Nitrogen and phosphorus nutrition of cattle. CABI Publishing, Cambridge, USA.

Jones-Endsley, J.M., M.J. Cecava, and T.R. Johnson. 1997. Effects of dietary supplementation on nutrient digestion and the milk yield of intensively grazed lactating dairy cows. Journal of Dairy Science 80:3283-3292.

Johnson, R.R. 1976. Influence of carbohydrate solubility on nonprotein nitrogen utilization in the ruminant. Journal of Animal Science 43:184-191.

Kaswari, T., P. Lebzien, G. Flachowsky, and U. Ter Meulen. 2007. Studies on the relationship between the synchronization index and the microbial protein synthesis in the rumen of dairy cows. Animal Feed Science and Technology 139:1-22.

Keady, T.W., C.S. Mayne, and M. Marsden. 1998 The effects of concentrate energy source on silage intake and animal performance with lactating dairy cows offered a range of grass silage. Animal Science 66:21-33.

Kolver, E.S., L.D. Muller, M.C. Barry, and J.W. Penno. 1998. Evaluation and application of the cornell net carbohydrate and protein system for dairy cows fed diets based on pasture. Journal of Dairy Science 81:2029-2039.

Kulling, D.R., H. Menzi, T.F. Kröber, A. Neftel, F. Sutter, P. Lischer, and M. Kreuzer. 2001. Emissions of ammonia, nitrous oxide and methane from different types of dairy manure during storage as affected by dietary protein content. Journal of Agricultural Science 137:235-250

Lapierre, H., R. Berthiaume, G. Raggio, M.C. Thivierge, L. Doepel, D. Pacheco, et al. 2005. The route of absorbed nitrogen into milk protein. Animal Science 80:11-22.

Lund, P., K. Søegaard, and M.R. Weisbjerg. 2008. Effect of strategies regarding concentrate supplementation and day-time grazing on $\mathrm{N}$ utilization at both field and dairy cow level. Livestock Science 114:93-107.

Marini, J.C., J.D. Klein, J.M. Sands, and M.E. Van Amburgh. 2004. Effect of nitrogen intake on nitrogen recycling and urea transporter abundance in lambs. Journal of Animal Science 82:1157-1164.

McBride, B.W., and J.M. Kelly. 1990. Energy cost of absorption and metabolism in the ruminant gastrointestinal tract and liver: a review. Journal of Animal Science 68:2997-3010.

Miller, L.A., J.M. Moorby, D.R. Davies, M.O. Humphreys, N.D. Scollan, J.C. MacRae, and M.K. Theodorou. 2001. Increased concentration of water soluble carbohydrate in perennial ryegrass (Lolium perenne L.): Milk production from late-lactation dairy cows. Grass and Forage Science 56:383-394.

Moorby, J.M., R.T. Evans, N.D. Scollan, J.C. MacRae, and M.K. Theodorou. 2006. Increased concentration of water-soluble carbohydrate in perennial ryegrass (Lolium perenne L.) Evaluation in dairy cows in early lactation. Grass and Forage Science 61:5259.

Mulligan, F.J., P. Dillon, J.J. Callan, M. Rath, and F.P.O. O'Mara. 2004. Supplementary concentrate type affects nitrogen excretion of grazing dairy cows. Journal of Dairy Science 87:3451-3460

Newbold, J.R., and S.R. Rust. 1992. Effect of asynchronous nitrogen and energy supply on growth of ruminal bacteria in batch culture. Journal of Animal Science 70:538-546.

Nolan, J.V., and R.C. Dobos. 2005. Nitrogen transactions in ruminants. p. 177-206. In Dijkstra, J., J.M. Forbes, and J. France (eds.) Quantitative aspects of ruminant digestion and metabolism. $2^{\text {nd }}$ ed. CABI Publishing, Wallingford, UK.

NRC. 2001. Nutrient requirements of dairy cattle. 381 p. $7^{\text {th }}$ ed. National Academy Press, Washington D.C., USA.

O'Mara, F.P., G.K. Stakelum, P. Dillon, J.J. Murphy, and M. Rath. 1997. Rumen fermentation and nutrient flows for cows fed grass and grass supplemented with molassed beet pulp pellets. Journal of Dairy Science 80:2466-2474.

Pacheco, D., B.A. Barrett, G.P. Cosgrove, R.E. Vibart, and G.C. Waghorn. 2008. Optimising nitrogen utilisation in pastoral dairy farming: Challenges and opportunities. In Simposio Internacional
"Optimizando la función ruminal en sistemas a pastoreo". XXXIII Reunión Anual SOCHIPA. Valdivia, Chile. 29-31 October 2008 Sociedad Chilena de Producción Animal A.G. (SOCHIPA), Valdivia, Chile.

Pacheco, D., and G.C. Waghorn. 2008. Dietary nitrogen definitions, digestion, excretion and consequences of excess for grazing ruminants. Proceedings of the New Zealand Grassland Association 70:107-116.

Peyraud, J.L., and L. Astigarraga. 1998. Review of the effect of nitrogen fertilization on the chemical composition, intake, digestion and nutritive value of fresh herbage: consequences on animal nutrition and $\mathrm{N}$ balance. Animal Feed Science and Technology 72:235-259

Reis, R.B., and D.K. Combs. 2000. Effects of increasing levels of grain supplementation on rumen environment and lactation performance of dairy cows grazing grass-legume pasture. Journal of Dairy Science 83:2888-2898.

Robaina, A.C., C. Grainger, P. Moate, J. Taylor, and J. Stewart. 1998 Responses to grain feeding by grazing dairy cows. Australian Journal of Experimental Agriculture 38:541-549.

Rutter, S.M., R.J. Orr, N.H. Yarrow, and R.A. Champion. 2004 Dietary preference of dairy cows grazing ryegrass and white clover. Journal of Dairy Science 87:1317-1324.

Satter, L.D., T.J. Klopfenstein, and G.E. Erickson. 2002. The role of nutrition in reducing nutrient output from ruminants. Journal of Animal Science 80:143-156.

Schwab, C., P. Huhtanen, C. Hunt, and T. Hvelplund. 2005. Nitrogen requirements of cattle. p. 14-70. In Pfeffer, E., and A.N Hristov (eds.) Nitrogen and phosphorus nutrition of cattle. CABI Publishing, Cambridge, USA.

Shabi, Z.,A.Arieli, I. Bruckental, Y. Aharoni, S.Zamwel, A. Bor, and H. Tagari. 1998. Effect of the synchronization of the degradation of dietary crude protein and organic matter and feeding frequency on ruminal fermentation and flow of digesta in the abomasum of dairy cows. Journal of Dairy Science 81:1991-2000.

Steinshamn, H., M. Höglind, T. Garmo, E. Thuen, and U. Brenøe. 2006. Feed nitrogen conversion in lactating dairy cows on pasture as affected by concentrate supplementation. Animal Feed Science and Technology 131:25-41.

Tamminga, S. 1986. Utilization of naturally occurring NPNcompounds by ruminants. Archives of Animal Nutrition 36:169176.

Tas, B.M., H.Z. Taweel, H.J. Smit, A. Elgersma, J. Dijkstra, and S Tamminga. 2006a. Utilisation of $\mathrm{N}$ in perennial ryegrass cultivars by stall-fed lactating dairy cows. Livestock Science 100:159-168

Tas, B.M., H.Z. Taweel, H.J. Smit, A. Elgersma, J. Dijkstra, and S Tamminga. 2006b. Effects of perennial ryegrass cultivars on milk yield and nitrogen utilization in grazing dairy cows. Journal of Dairy Science 89:3494-3500.

Taweel, H.Z. 2006. Improving dry matter intake of perennial ryegrass pasture by dairy cows. p. 175-1194. In Elgersma A., J. Dijkstra, and S. Taminga (eds.) Fresh herbage for dairy cattle. Springer, Dordrecht, The Netherlands.

Taweel, H.Z., B.M. Tas, H.J. Smit, A. Elgersma, J. Dijkstra, and S Tamminga. 2005. Effects of feeding perennial ryegrass with an elevated concentration of water-soluble carbohydrates on intake, rumen function and performance of dairy cows. Animal Feed Science and Technology 121:243-256.

Taweel, H.Z., B.M. Tas, H.J. Smit, A. Elgersma, J. Dijkstra, and S Tamminga. 2006. Grazing behaviour, intake, rumen function and milk production of dairy cows offered Lolium perenne containing different levels of water-soluble carbohydrates. Livestock Science 102:33-41.

Trevaskys, L.M., W.J.Fulkerson, and K.S. Nandra. 2004. Effect of time of feeding carbohydrate supplements and pasture on production of dairy cows. Livestock Production Science 85:275-285.

Van Vuuren, A.M., S. Tamminga, and R.S. Ketelaar. 1990. Ruminal availability of nitrogen and carbohydrates from fresh and preserved herbage in dairy cows. Netherland Journal of Agricultural Science $38: 499-512$ 
Van Vuuren, A.M., C.J. Van Der Koelen, and J. Vroone-De Bruin. 1993. Ryegrass versus corn starch or beet pulp fiber diet effects on digestion and intestinal amino acids in dairy cows. Journal of Dairy Science 76:2692-2700.

Verité, R., and L. Delaby. 2000. Relation between nutrition, performances and nitrogen excretion in dairy cows. Annales de Zootechnie 49:217-230.
Wales, W.J., E.S. Kolver, and A.R. Egan. 2009. Digestion during continuous culture fermentation when replacing perennial ryegrass with barley and steam-flaked corn. Journal of Dairy Science 92:189-196.

Walker, G.P., C. Stockdale, W. Wales, P. Doyle, and D. Dellow. 2001. Effect of level of grain supplementation on milk production responses of dairy cows in mid-late lactation when grazing irrigated pastures high in paspalum (Paspalum dilatatum Poir.). Australian Journal of Experimental Agriculture 41:1-11. 